\title{
Snow cover duration trends observed at sites and predicted by multiple models
}

\author{
Richard Essery ${ }^{1}$, Hyungjun Kim ${ }^{2}$, Libo Wang ${ }^{3}$, Paul Bartlett ${ }^{3}$, Aaron Boone ${ }^{4}$, Claire Brutel-Vuilmet ${ }^{5}$, \\ Eleanor Burke $^{6}$, Matthias Cuntz ${ }^{7}$, Bertrand Decharme ${ }^{4}$, Emanuel Dutra ${ }^{8}$, Xing Fang ${ }^{9}$, Yeugeniy Gusev ${ }^{10}$, \\ Stefan Hagemann $^{11}$, Vanessa Haverd ${ }^{12}$, Anna Kontu ${ }^{13}$, Gerhard Krinner ${ }^{5}$, Matthieu Lafaysse ${ }^{14}$, Yves Lejeune $^{14}$, \\ Thomas Marke $^{15}$, Danny Marks ${ }^{16}$, Christoph Marty ${ }^{17}$, Cecile B. Menard ${ }^{1}$, Olga Nasonova ${ }^{10}$, Tomoko Nitta $^{2}$, \\ John Pomeroy ${ }^{9}$, Gerd Schädler ${ }^{18}$, Vladimir Semenov ${ }^{19}$, Tatiana Smirnova ${ }^{20}$, Sean Swenson ${ }^{21}$, Dmitry Turkov ${ }^{22}$, \\ Nander Wever ${ }^{17,23}$, and Hua Yuan ${ }^{24}$
}

${ }^{1}$ School of GeoSciences, University of Edinburgh, Edinburgh, UK

${ }^{2}$ Institute of Industrial Science, University of Tokyo, Tokyo, Japan

${ }^{3}$ Climate Research Division, Environment and Climate Change Canada, Toronto, Canada

${ }^{4}$ Université de Toulouse, Météo-France, CNRS, Toulouse, France

${ }^{5}$ CNRS, Université Grenoble Alpes, Institut de Géosciences de l'Environnement, Grenoble, France

${ }^{6}$ Met Office, Exeter, UK

${ }^{7}$ Université de Lorraine, AgroParisTech, INRAE, UMR Silva, Nancy, France

${ }^{8}$ Instituto Dom Luiz, Faculdade de Ciências, Universidade de Lisboa, Lisbon, Portugal

${ }^{9}$ Centre for Hydrology, University of Saskatchewan, Saskatoon, Canada

${ }^{10}$ Institute of Water Problems, Russian Academy of Sciences, Moscow, Russia

${ }^{11}$ Institute of Coastal Research, Helmholtz-Zentrum Geesthacht, Geesthacht, Germany

${ }^{12}$ CSIRO Oceans and Atmosphere, Canberra, ACT, Australia

${ }^{13}$ Space and Earth Observation Centre, Finnish Meteorological Institute, Sodankylä, Finland

${ }^{14}$ Météo-France, CNRS, CNRM, Centre d'Etudes de la Neige, Grenoble, France

${ }^{15}$ Department of Geography, University of Innsbruck, Innsbruck, Austria

${ }^{16}$ USDA Agricultural Research Service, Boise, ID, USA

${ }^{17}$ WSL Institute for Snow and Avalanche Research SLF, Davos, Switzerland

${ }^{18}$ Institute of Meteorology and Climate Research, Karlsruhe Institute of Technology, Karlsruhe, Germany

${ }^{19}$ A.M. Obukhov Institute of Atmospheric Physics, Russian Academy of Sciences, Moscow, Russia

${ }^{20}$ Cooperative Institute for Research in Environmental Science/Earth System Research Laboratory, NOAA, Boulder, CO, USA

${ }^{21}$ Climate and Global Dynamics Division, National Center for Atmospheric Research, Boulder, CO, USA

${ }^{22}$ Institute of Geography, Russian Academy of Sciences, Moscow, Russia

${ }^{23}$ Department of Atmospheric and Oceanic Sciences, University of Colorado, Boulder, CO, USA

${ }^{24}$ School of Atmospheric Sciences, Sun Yat-sen University, Guangzhou, China

Correspondence: Richard Essery (richard.essery@ed.ac.uk)

Received: 29 June 2020 - Discussion started: 28 July 2020

Revised: 6 November 2020 - Accepted: 18 November 2020 - Published: 21 December 2020 
Abstract. The 30-year simulations of seasonal snow cover in 22 physically based models driven with bias-corrected meteorological reanalyses are examined at four sites with long records of snow observations. Annual snow cover durations differ widely between models, but interannual variations are strongly correlated because of the common driving data. No significant trends are observed in starting dates for seasonal snow cover, but there are significant trends towards snow cover ending earlier at two of the sites in observations and most of the models. A simplified model with just two parameters controlling solar radiation and sensible heat contributions to snowmelt spans the ranges of snow cover durations and trends. This model predicts that sites where snow persists beyond annual peaks in solar radiation and air temperature will experience rapid decreases in snow cover duration with warming as snow begins to melt earlier and at times of year with more energy available for melting.

\section{Introduction}

The extensive seasonal snow cover of Northern Hemisphere land is sensitive to climate warming and strongly influences surface-atmosphere interactions, so it is important that climate models should be able to simulate it accurately. Observed changes in snow cover extent have been used as evidence for climate change and to evaluate climate models in all five Intergovernmental Panel on Climate Change (IPCC) Working Group 1 Assessment Reports to date. Strong relationships between decreasing snow cover and increasing air temperature have been demonstrated in observations and in multi-model simulations for the Coupled Model Intercomparison Project (CMIP) coordinated by the World Climate Research Programme. Although the reproduction of seasonal snow cover by climate models has improved, CMIP5 simulations underestimated significant reductions observed in spring snow cover extent (Brutel-Vuilmet et al., 2013) and had a wide spread in predictions of snow-albedo feedback strength (Qu and Hall, 2014). In preparation for the sixth IPCC assessment report, climate modelling centres have now performed CMIP6 coupled land-atmosphere-ocean simulations with their latest models. Mudryk et al. (2020) report an overall better representation of Northern Hemisphere snow cover extent in the CMIP6 multi-model ensemble than in CMIP5, but a large spread remains in simulated trends.

In addition to coupled model experiments, snow simulations by stand-alone land surface models have been driven with prescribed meteorological variables on global grids in the Global Soil Wetness Project (Dirmeyer et al., 2006) and at individual sites in the Project for Intercomparison of Land-surface Parameterization Schemes (Slater et al., 2001) and the Snow Model Intercomparison Project (Etchevers et al., 2004; Essery et al., 2009). These studies have invariably found wide ranges in simulations and inconsisten- cies in model performance. The Earth System Model-Snow Model Intercomparison Project (ESM-SnowMIP; Krinner et al., 2018) includes simulations driven with both in situ meteorological measurements and bias-corrected reanalyses at 10 well-instrumented snow study sites; simulations with between 7 and 20 years of in situ driving data have been evaluated by Menard et al. (2020), but using reanalyses allows longer simulations for investigating trends. This paper examines observed trends in seasonal snow cover duration and simulations driven with 1980-2010 bias-corrected reanalyses at four of the ESM-SnowMIP sites selected because they had at least 27 years of daily snow observations up to 2010. The locations of the sites are given in Table 1. Reflecting motivations for the establishment of snow study sites by national organizations, Col de Porte (France), Reynolds Mountain East (USA), and Weissfluhjoch (Switzerland) are at high elevations in mid-latitude mountains, whereas Sodankylä (Finland) is a low-elevation Arctic site. All of the sites typically have between 5 and 8 months of continuous winter snow cover and can have shorter periods of ephemeral snow cover at other times of year.

Simple empirical models of snowmelt are still often used for hydrological and glaciological applications, but all of the models participating in ESM-SnowMIP are physically based and calculate coupled mass and energy balances for snow on the ground. Eighteen groups submitted simulations by 22 models and model variants driven with a common set of bias-corrected reanalyses provided by the third Global Soil Wetness Project (GSWP3; Kim, 2017) for the Land Surface, Snow and Soil moisture Model Intercomparison Project (LS3MIP; van den Hurk et al., 2016). The models include land surface schemes that are commonly coupled to atmospheric models (CABLE, CLASS, CLM5, CoLM, EC-Earth, ISBA, MATSIRO, RUC, two versions of JSBACH, three configurations of JULES, and two versions of ORCHIDEE), stand-alone land surface or hydrology models (CRHM, ESCIMO, SPONSOR, SWAP, and Veg3D), and snow physics models (Crocus and SNOWPACK); references for all of these models can be found in Table 1 of Krinner et al. (2018). Although snow models are much less complex than comprehensive Earth system models, they have sufficient complexity and large enough parameter spaces to make it difficult to interpret why they behave in the ways that they do. For Earth system models, Randall et al. (2019) concluded that "we must work to create much simpler models that can semiquantitatively reproduce the key results of the comprehensive models". In that spirit, a highly simplified two-parameter energy balance model (" $2 \mathrm{PM}$ " hereafter) is used to interpret the results of the ESM-SnowMIP models.

\section{Methods}

All of the meteorological variables required to drive physically based mass and energy balance snow models (air tem- 
Table 1. Site locations and $0.5^{\circ}$ grid elevations.

\begin{tabular}{lrrrr}
\hline Site & Latitude & Longitude & Elevation & Grid elevation \\
\hline Col de Porte & $45.30^{\circ} \mathrm{N}$ & $5.77^{\circ} \mathrm{E}$ & $1325 \mathrm{~m}$ & $870 \mathrm{~m}$ \\
Reynolds Mountain East & $43.19^{\circ} \mathrm{N}$ & $116.78^{\circ} \mathrm{W}$ & $2060 \mathrm{~m}$ & $1260 \mathrm{~m}$ \\
Sodankylä & $67.37^{\circ} \mathrm{N}$ & $26.63^{\circ} \mathrm{E}$ & $179 \mathrm{~m}$ & $220 \mathrm{~m}$ \\
Weissfluhjoch & $46.83^{\circ} \mathrm{N}$ & $9.81^{\circ} \mathrm{E}$ & $2536 \mathrm{~m}$ & $1930 \mathrm{~m}$ \\
\hline
\end{tabular}

perature, humidity and pressure, snowfall and rainfall rates, shortwave and longwave radiation fluxes, and wind speed) for 1980-2010 at the ESM-SnowMIP sites were extracted from the GSWP3 dataset and interpolated from 3-hourly to hourly time steps. For GSWP3, the 20th Century Reanalysis was used to nudge the dynamics of a global spectral model for downscaling from $2^{\circ}$ to $0.5^{\circ}$ resolution (Yoshimura and Kanamitsu, 2008). Biases in monthly means of temperature, diurnal temperature range, precipitation, and radiation fluxes relative to Climate Research Unit Time-Series (CRUTS) Global Precipitation Climatology Centre and Surface Radiation Budget (SRB) datasets were then removed. Additional bias corrections had to be applied for ESM-SnowMIP site simulations because the mountain sites are at much higher elevations than the $0.5^{\circ}$ GSWP3 grid cells in which they lie (Table 1). Biases relative to in situ measurements for overlapping periods at each site were simply removed for all driving variables, thus preserving distribution shapes, seasonal cycles, and trends from the GSWP3 dataset (Menard et al., 2019). The meteorological variables extracted from GSWP3, interpolated to hours and bias-corrected to the sites, are referred to as the driving data for the ESM-SnowMIP models hereafter. Because coupling to an atmospheric model was not required, snow models that are not part of an Earth system model were also able to participate in this component of ESM-SnowMIP.

The simplified model that will be used for interpreting the ESM-SnowMIP results below has two fixed dimensionless parameters: a snow albedo $\alpha$ and a surface-atmosphere turbulent exchange coefficient $C_{H}$. Although the cold content of snow is represented in more sophisticated models, a large simplification in 2PM comes from neglecting heat required to warm snow to the melting point in comparison with heat required to melt snow $(21 \mathrm{~kJ}$ will warm $1 \mathrm{~kg}$ of snow from -10 to $0^{\circ} \mathrm{C}$ but will only melt $63 \mathrm{~g}$ of snow at $0^{\circ} \mathrm{C}$ ). Snowmelt rate $M\left(\mathrm{~kg} \mathrm{~m}^{-2} \mathrm{~s}^{-1}\right)$ is predicted by the energy balance equation

$\lambda_{\mathrm{m}} M=(1-\alpha) \mathrm{SW}_{\downarrow}+\mathrm{LW}_{\downarrow}-\sigma T_{\mathrm{s}}^{4}-H-\lambda_{\mathrm{s}} E$,

with latent heat of melting $\lambda_{\mathrm{m}}\left(0.334 \times 10^{6} \mathrm{~J} \mathrm{~kg}^{-1}\right)$, latent heat of sublimation $\lambda_{\mathrm{s}}\left(2.835 \times 10^{6} \mathrm{~J} \mathrm{~kg}^{-1}\right)$, surface temperature $T_{\mathrm{s}}(\mathrm{K})$, and Stefan-Boltzmann constant $\sigma(5.67 \times$ $\left.10^{-8} \mathrm{~W} \mathrm{~m}^{-2} \mathrm{~K}^{-4}\right) ; \mathrm{SW}_{\downarrow}$ and $\mathrm{LW}_{\downarrow}\left(\mathrm{W} \mathrm{m}^{-2}\right)$ are downward shortwave and longwave radiation fluxes, and heat advected by rain falling on snow is neglected. Sensible heat flux $H$
$\left(\mathrm{W} \mathrm{m}^{-2}\right)$ and moisture flux $E\left(\mathrm{~kg} \mathrm{~m}^{-2} \mathrm{~s}^{-1}\right)$ between the surface and the atmosphere are parameterized using the bulk formulae

$H=\rho c_{p} C_{H} U\left(T_{\mathrm{s}}-T_{\mathrm{a}}\right)$

and

$E=\rho C_{H} U\left[q_{\mathrm{sat}}\left(T_{\mathrm{s}}, p\right)-q_{\mathrm{a}}\right]$

for air pressure $p(\mathrm{~Pa})$, temperature $T_{\mathrm{a}}$, specific humidity $q_{\mathrm{a}}$, heat capacity $c_{p}\left(1005 \mathrm{~J} \mathrm{~K}^{-1} \mathrm{~kg}^{-1}\right)$, and density $\rho\left(\mathrm{kg} \mathrm{m}^{-3}\right)$; $U\left(\mathrm{~m} \mathrm{~s}^{-1}\right)$ is wind speed and $q_{\text {sat }}$ is the specific humidity of saturated air. Equations (1) to (3) are first solved for unknown $T_{\mathrm{s}}$ with $M=0$. If this gives a temperature greater than $T_{\mathrm{m}}=273.15 \mathrm{~K}$ while there is snow on the ground, the equations are solved again for unknown $M$ with $T_{\mathrm{s}}=T_{\mathrm{m}}$. Melt and sublimation rates are then used with snowfall rate $S_{f}$ $\left(\mathrm{kg} \mathrm{m}^{-2} \mathrm{~s}^{-1}\right)$ each hour in the mass balance equation

$\frac{\mathrm{d} S}{\mathrm{~d} t}=S_{f}-E-M$

to predict changes in snow mass $S\left(\mathrm{~kg} \mathrm{~m}^{-2}\right)$, which is limited to be greater than or equal to zero and is converted to depth using a fixed snow density of $300 \mathrm{~kg} \mathrm{~m}^{-3}$. 2PM was run 10000 times for each site with snow albedos ranging from 0.5 to 1 and turbulent exchange coefficients ranging from $10^{-4}$ to $10^{-2}$.

\section{Results}

Figure 1 shows monthly means and trends in air temperatures measured at the sites and in the driving data; averages and ranges of observed start and end dates for continuous seasonal snow cover with depths exceeding $2 \mathrm{~cm}$ are also shown. The seasonal temperature cycle and trends in the driving data match observations closely at Sodankylä because the station there was included in the CRUTS database used for correcting GSWP3 temperatures. Weissfluhjoch is $60 \mathrm{~km}$ from the closest CRUTS station at Säntis but only $50 \mathrm{~m}$ higher. There are larger elevation differences for the CRUTS stations nearest to Col de Porte (Lyon, $75 \mathrm{~km}$ away and $1125 \mathrm{~m}$ lower) and Reynolds Mountain East (Boise, $65 \mathrm{~km}$ away and $1190 \mathrm{~m}$ lower), but temperature trends in the driving data are still similar to observations, particularly for significant trends 

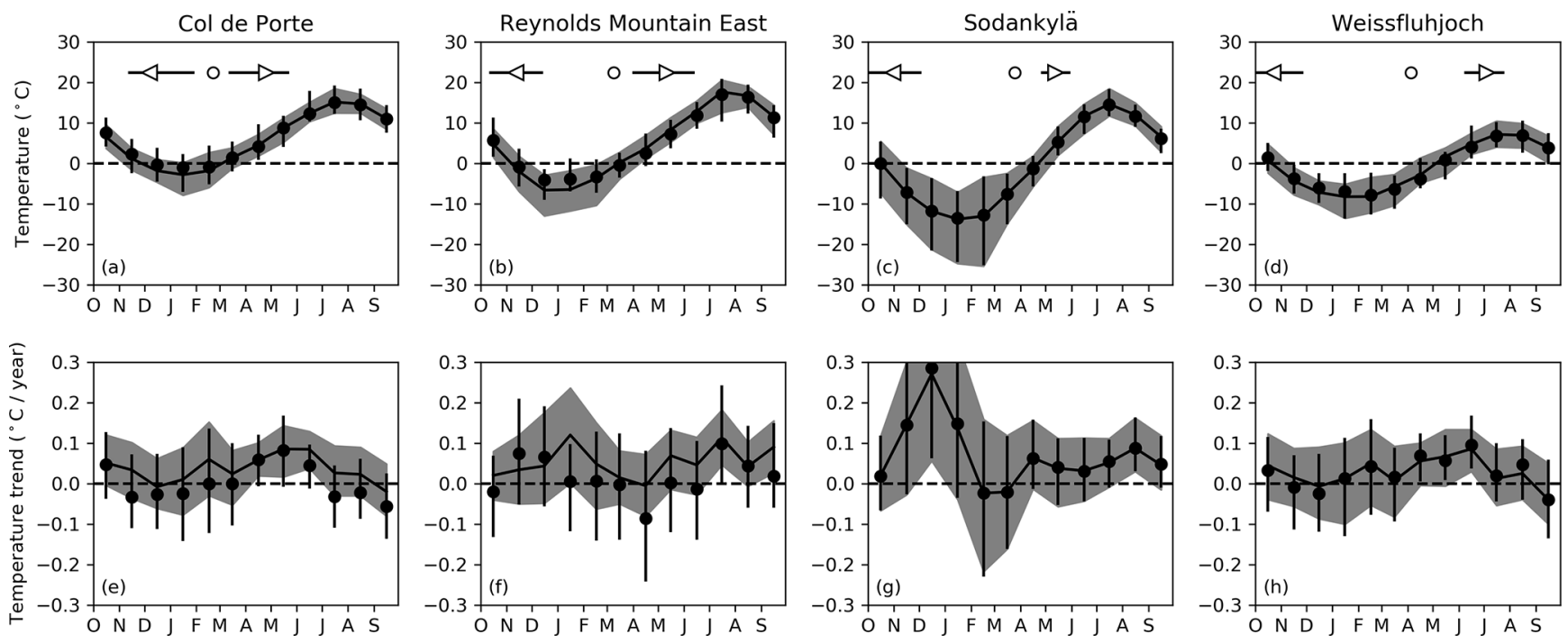

Figure 1. (a-d) Monthly-mean temperatures calculated from measurements at the sites (filled circles) and the driving data (lines). Vertical bars for measurements and grey bands for driving data show ranges between the warmest and coolest months from October 1980 to September 2010. Triangles and horizontal bars show averages and ranges of observed start $(\triangleleft)$ and end $(\triangleright)$ dates of continuous seasonal snow cover. Open circles show average dates of maximum snow depth. (e-h) Temperature trends for each month, calculated by the Theil-Sen method (Sen, 1968). Vertical bars for measurements and grey bands for driving data show $95 \%$ confidence intervals.

(i.e. when $95 \%$ confidence intervals do not cross zero). The driving data have significant 1980-2010 warming trends for April to June at Col de Porte, July and September at Reynolds Mountain East, August and December at Sodankylä, and June at Weissfluhjoch. The rapid December warming at Sodankylä will not directly influence simulated snow cover durations because it corresponds with a reduction in the occurrence of very low temperatures at times when snow is not melting. Other warming trends at Reynolds Mountain East and Sodankylä occur during snow-free months, but warming trends at Col de Porte and Weissfluhjoch overlap the normal periods of snowmelt.

The snow cover duration observations in Fig. 1 are shown again in Fig. 2 for comparison with seasonal cycles of incoming shortwave and longwave radiation. The SRB dataset used to correct biases in surface radiation fluxes for GSWP3 was produced from satellite measurements but has been validated against measurements at Baseline Surface Radiation Network (BSRN) stations (Zhang et al., 2013, 2015). Although the four sites studied here are not BSRN stations, there is generally good agreement between radiation fluxes in the driving data and observations at the sites. An exception is that the observed seasonal cycle of shortwave radiation peaks in May at Weissfluhjoch because of seasonal variations in cloud cover and multiple reflections between high-albedo snow and clouds, whereas the driving data peak in late June. Weissfluhjoch is also unique among the sites in that continuous snow cover can persist beyond the annual peak in solar radiation.
Solid precipitation is notoriously difficult to measure accurately, and quality-controlled measurements of snowfall are not available for all years back to 1980 at all of the sites. Annual snowfall amounts derived from precipitation gauge measurements are therefore only shown for comparison with the driving data in Fig. 3, and snowfall trends will only be investigated in the driving data. Weissfluhjoch is the only site with a significant downward trend in snowfall at the $95 \%$ confidence level, although Col de Porte has a downward trend with a $90 \%$ confidence interval from -15 to $-0.4 \mathrm{~mm} \mathrm{yr}^{-1}$. In contrast with the lack of trend at Reynolds Mountain East, Nayak et al. (2010) found significant decreases in the fractions of annual precipitation falling as snow at lower elevations in the Reynolds Creek Experimental Watershed. Sodankylä had higher snowfall in the 1990s than in the 1980s and 2000s in both the site measurements and the driving data, and no overall snowfall trend from 1980 to 2010. Irannezhad et al. (2016), however, found a significant decreasing winter precipitation trend at Sodankylä in a longer series of measurements from 1909 to 2008. Figures 1 and 3 together show that Sodankylä has the lowest winter temperatures and the lowest snowfall of the sites; Col de Porte has the warmest winter temperatures and the shortest seasonal snow cover; Weissfluhjoch has the highest snowfall, coolest summer temperatures, and longest seasonal snow cover.

Start and end dates for seasonal snow cover were found by searching for the last date with snow depths less than $2 \mathrm{~cm}$ before the maximum snow depth in each year and the first such date after the maximum. Figure 4 shows averages and trends for start and end dates in observations and simulations 

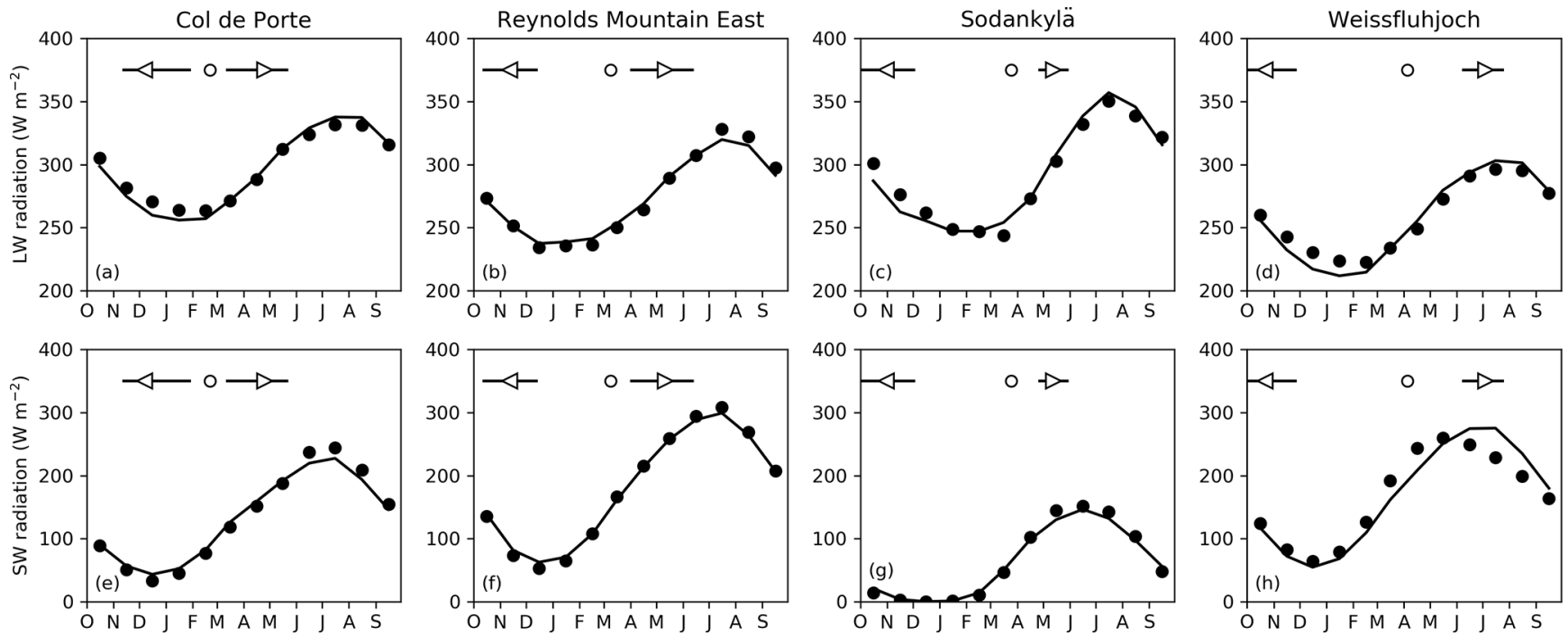

Figure 2. Monthly means of (a-d) incoming longwave radiation and (e-h) incoming shortwave radiation from measurements at the sites (filled circles) and the driving data (lines). Horizontal bars show ranges of observed start and end dates of continuous seasonal snow cover as in Fig. 1.
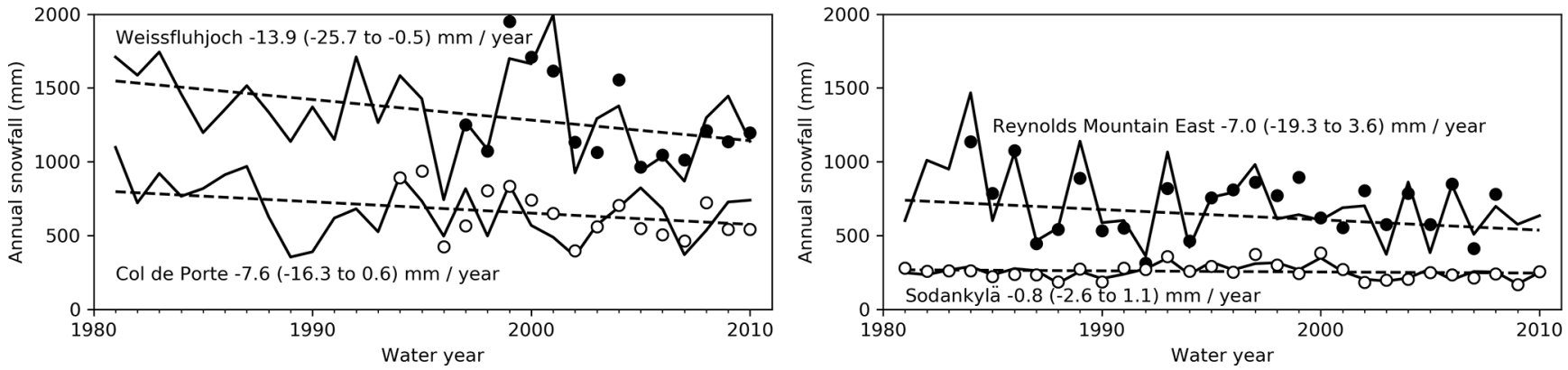

Figure 3. Water equivalent snowfall calculated from measurements at the sites (open and filled circles) and the driving data (solid lines) for water years starting on 1 October. Driving data trends are given with $95 \%$ confidence intervals in parentheses.

at all of the sites (annual time series from which these were calculated are shown in additional Fig. A1). Simulated start dates are largely determined by snowfall in the driving data and show relatively little spread between the models, except that some models will melt early snowfall at Col de Porte and others will retain it on the ground. Trends towards later start dates are observed at all sites and in most model simulations, but none of these trends are found to be significant with $95 \%$ confidence. Simulated end dates are influenced by differences in how models respond to increasing air temperatures and solar radiation in spring, leading to larger spreads between models. The spread is particularly large for Weissfluhjoch; two of the models melt snow consistently earlier than the others, and three models retain year-round snow cover in some years (which has never been observed in measurements going back to 1936 at Weissfluhjoch). Years in which a model does not melt the snow are excluded from calculations of end dates. Significant trends towards earlier snow disappearance are observed at Col de Porte and Weiss- fluhjoch but not at Reynolds Mountain East or Sodankylä, and most models lie within the confidence intervals of the observed trends. Fifteen of the $22 \mathrm{Col}$ de Porte simulations and all of the Weissfluhjoch simulations have significant trends. Reductions in snow cover have previously been detected using the same observations at Col de Porte by Lejeune et al. (2019) and at Weissfluhjoch by Marty and Meister (2012). The remaining discussion here will focus on model behaviour at those two sites.

The unrealistically wide parameter ranges in 2PM give results that encompass and extend beyond the ESM-SnowMIP model results in Fig. 4. 2PM simulations that melt snow later in the year at Col de Porte and Weissfluhjoch have stronger negative trends in continuous snow cover end dates. The same behaviour for ESM-SnowMIP models is seen most clearly for Weissfluhjoch simulations in Fig. 4d.

Snow albedo and turbulent exchanges between the surface and the atmosphere vary with time in reality and in realistic models, but $2 \mathrm{PM}$ results can be plotted as contours or a 

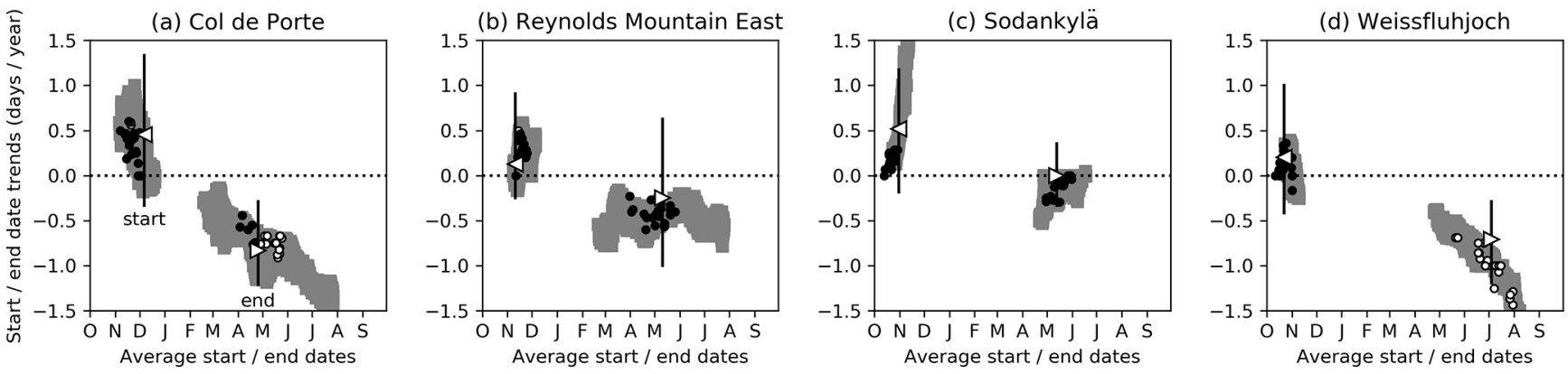

Figure 4. Scatter plots of averages and trends in start and end dates of continuous seasonal snow cover observed at the sites (triangles) and predicted by the ESM-SnowMIP models (open circles for significant trends, filled circles for insignificant trends) and 2PM (grey). Vertical bars show $95 \%$ confidence intervals on observed start $(\triangleleft)$ and end $(\triangleright)$ date trends.

(a) Col de Porte

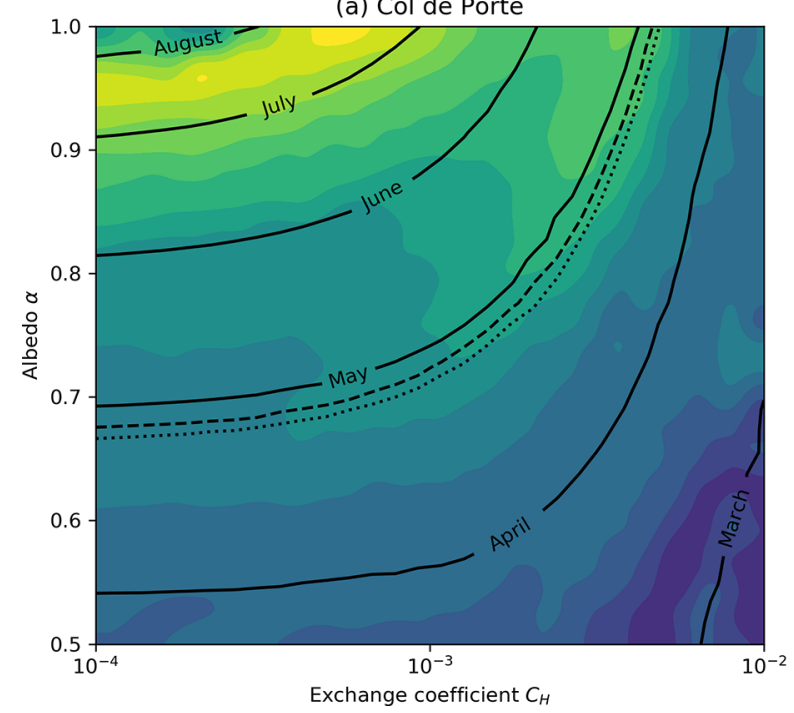

(b) Weissfluhjoch

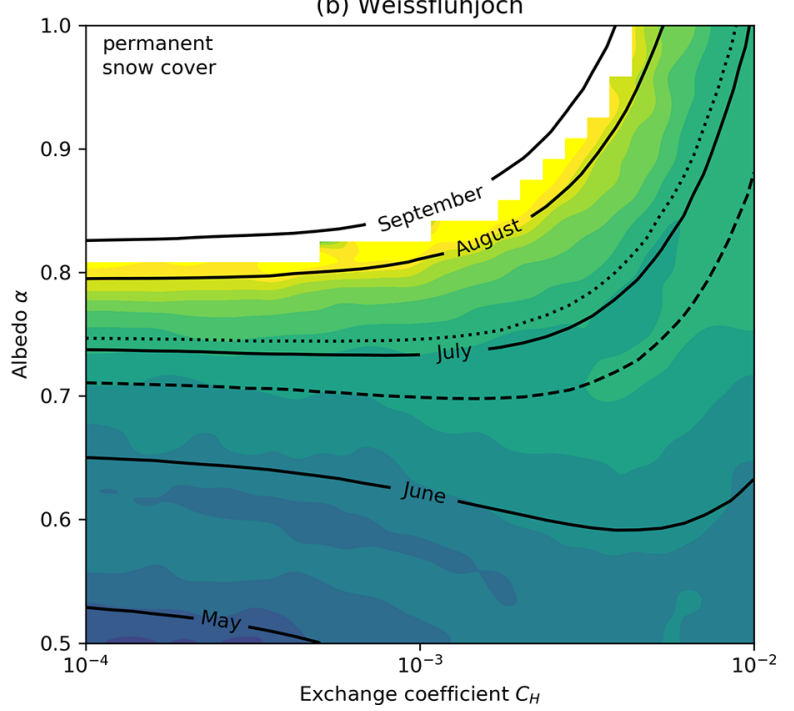

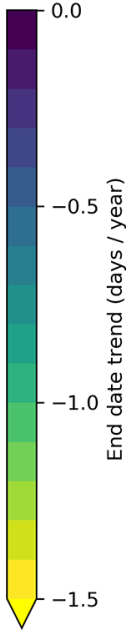

Figure 5. Averages (solid contours) and trends (colours) for continuous snow cover end dates in 2PM simulations at (a) Col de Porte and (b) Weissfluhjoch, excluding simulations with permanent snow cover. Dotted lines are contours for average observed snow cover end dates, and dashed lines are dates of maximum warming trends in the driving data (Fig. 1).

colour scale on the fixed $\alpha-C_{H}$ parameter space. Figure 5 overlays contours for snow cover end dates on colour maps of end date trends. Snowmelt becomes independent of air temperature as exchange coefficients approach zero and independent of solar radiation as albedos approach 1 . Lower albedos and larger exchange coefficients lead to earlier melt at $\mathrm{Col}$ de Porte, as might be expected. At Weissfluhjoch, however, low 2PM albedos can cause radiation-driven melt in May, when solar radiation is high but air temperatures are still often below $0^{\circ} \mathrm{C}$ (Fig. 1d); larger exchange coefficients then delay melt by cooling the snow, so the May and June contours curve downwards in Fig. 5b. Even in the absence of net solar radiation and sensible heat $\left(\alpha=1, C_{H}=0\right)$, there is sufficient longwave radiation in the driving data to melt the snow at Col de Porte each year, but the 2PM parameter space includes simulations that develop permanent snow cover at Weissfluhjoch (upper left corner of Fig. 5b) if the previous winter's snow has not melted by mid-August. Average observed and ESM-SnowMIP model snow cover end dates at Col de Porte fall in April or May; 2PM can produce a wide range of end date trends for snow melting in those months, seen as a bulge in Fig. 4a corresponding with a region where trend and end date contours cross in Fig. 5a. ESM-SnowMIP models that have average end dates close to the start of May for Col de Porte have trends at the less negative end of the 2PM range in Fig. 4a, consistent with small exchange coefficients characteristic of low roughness and high atmospheric stability over snow.

Trends in snow cover end date show two areas of the 2PM parameter space in Fig. 5 with enhanced negative trends. Strong trends for snow melting in July have already been noted in Fig. 4 and will be discussed again later. Enhanced trends also occur for snow cover ending in months with warming trends (Fig. 1), provided that exchange coefficients 

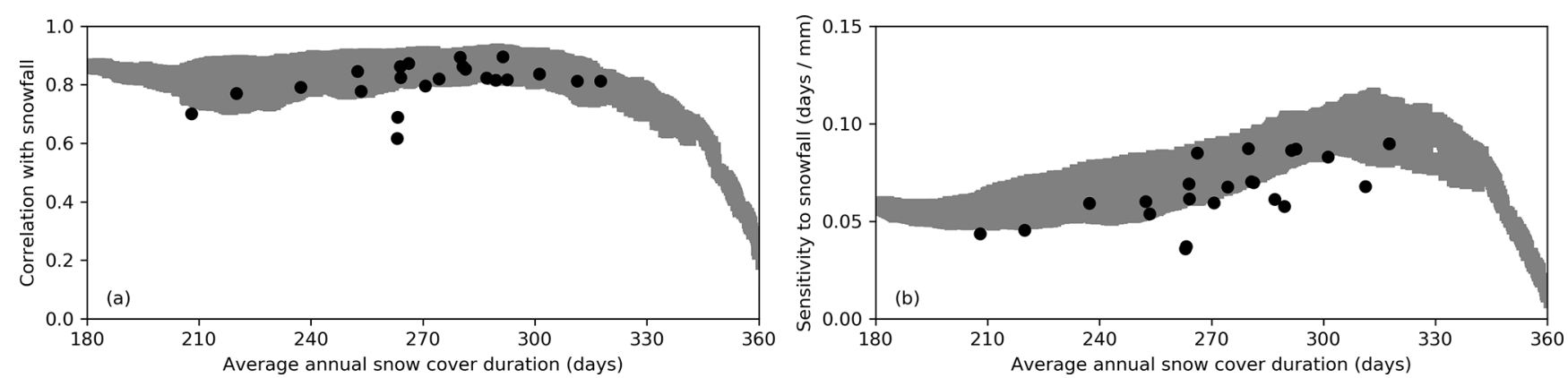

Figure 6. (a) Correlations between annual snow cover duration and snowfall amount in ESM-SnowMIP models (circles) and 2PM (grey band) at Weissfluhjoch. (b) Sensitivity of Weissfluhjoch snow cover duration to snowfall, expressed as increase in days of annual snow cover per millimetre of increase in annual snowfall found by linear regression.

are large enough for simulations to be sensitive to air temperature. This is apparent in Fig. 5 as protrusions of stronger trends along the end date contours for late April at Col de Porte and mid-June at Weissfluhjoch. The average observed end date of continuous snow cover (dotted contour) is close to the date of maximum temperature trend (dashed contour) at Col de Porte, as expected for a positive feedback on warming with decreasing snow cover duration. Snow disappears at Weissfluhjoch about 2 weeks later than the date of maximum warming, however. It may be that warming trends at Weissfluhjoch are dominated by advection from lower surrounding areas with earlier snowmelt; Col de Porte is at the 57th elevation percentile and Weissfluhjoch is at the 94th elevation percentile for $10 \mathrm{~km} \times 10 \mathrm{~km}$ areas centred on the sites. Warming is also expected to vary with elevation in mountain regions (Pepin et al., 2015).

Annual snow cover duration (SCD) depends on the timing of snowfall, how much snow has to be melted and how much energy is available to melt it. Figure 6a for Weissfluhjoch and Table 2 for all sites show that modelled interannual variations in SCD are highly correlated with annual snowfall, except at Sodankylä; low snowfall and rapid temperature increases from April to May at Sodankylä limit variations in the end date of snow cover, both between years and between models (Fig. 4c). Beyond the range of the ESM-SnowMIP models in Fig. 6a, correlations in 2PM simulations inevitably decrease as the model undergoes a transition from seasonal to permanent snow cover at Weissfluhjoch independent of annual snowfall. Incoming solar radiation in the driving data for Weissfluhjoch peaks around the summer solstice in late June (Fig. 2h), whereas energy available to melt snow from longwave radiation and sensible heat peak in late July (Figs. 1d and 2d). Snow persisting after the peak in available energy will melt more slowly, so additional snowfall increases SCD more for simulations that retain seasonal snow cover later. The sensitivity obtained by linear regression of SCD against snowfall, shown for Weissfluhjoch in Fig. 6b, therefore increases for late-lying snow. Because SCD is highly correlated with snowfall, increased sensitivity to snowfall in sim-
Table 2. Average correlations between simulated annual snow cover duration and annual snowfall.

\begin{tabular}{lrc}
\hline Site & ESM-SnowMIP & 2PM \\
\hline Col de Porte & 0.79 & 0.81 \\
Reynolds Mountain East & 0.77 & 0.82 \\
Sodankylä & 0.50 & 0.45 \\
Weissfluhjoch & 0.81 & 0.79 \\
\hline
\end{tabular}

ulations with late-lying snow and decreasing snowfall combine to amplify trends in SCD, as seen in Figs. 4 and 5 for both Col de Porte and Weissfluhjoch.

\section{Discussion and conclusions}

Despite wide spreads in simulated snow cover durations, trends in models are consistent with observations at the four ESM-SnowMIP sites with long records used here: trends towards seasonal snow cover starting later in the year are not significant at any of these sites, but there are significant trends towards seasonal snow cover ending earlier at $\mathrm{Col}$ de Porte and Weissfluhjoch (consistent with trends found across the Swiss Alps by Klein et al., 2016). Having been chosen for snow research in part because they have dependable seasonal snow cover, the ESM-SnowMIP sites are not in regions of marginal snow cover that are most vulnerable to warming. A compilation of multiple observation-based estimates of Northern Hemisphere snow cover extent shows maximum decreasing trends in November and March, coincident with peaks in surface temperature warming trends (Mudryk et al., 2017). Large-scale simulations are required for predicting large-scale trends in snow cover extent, but simulations at well-instrumented sites allow more insight into modelling of snow processes and impacts that are experienced on small scales.

Interannual variations in modelled snow cover duration are strongly correlated with annual snowfall in the driving data at three of the four sites, which means that the models are 
also strongly correlated with each other (additional Fig. A2) because they all shared the same driving data. This intermodel correlation will not be preserved when snow models are coupled to different atmospheric models. Coupling also allows feedbacks that are suppressed when snow models are driven with prescribed meteorology. Coupled simulations with prescribed snow conditions are proposed in ESMSnowMIP to evaluate the effects of snow feedbacks (Krinner et al., 2018). Because water will not be conserved if snow mass is prescribed independently of snowfall and melt, these should be land-atmosphere simulations with prescribed sea surface temperatures to avoid perturbations of the ocean by runoff that would occur in coupled land-atmosphere-ocean simulations.

A simple two-parameter snowmelt model shows that the response of snow models to warming in their driving data is stronger in simulations that melt snow close to the time of year when the warming is strongest and in simulations with stronger aerodynamic coupling between the surface and the atmosphere. For simulations with snow cover persisting past mid-summer, responses to decreasing snowfall are amplified by increasing availability of energy as snow melts earlier. The same behaviour is observed in the spread of ESMSnowMIP model snow cover end dates and trends for Weissfluhjoch; it should occur in reality for regions undergoing transitions from permanent to seasonal snow cover and on glaciers where the equilibrium line altitude is rising. This mechanism for amplification of snow climate sensitivity in addition to the well-known snow-albedo feedback has not been proposed before, as far as we are aware, but it complements the "slower snowmelt in a warmer world" hypothesized by Musselman et al. (2017) and observed on large scales by $\mathrm{Wu}$ et al. (2018) for snow melting in spring before the peak in available energy. López-Moreno et al. (2013) found accelerated melt rates in simulations with colder temperatures that delayed the start of melt until later dates with more intense solar radiation.
Conclusions drawn here have been based on simulations at a limited number of sites. The global land-only simulations now being performed for LS3MIP (van den Hurk et al., 2016) will provide an opportunity for testing these conclusions in a much wider range of climate conditions. 
Appendix A: Additional figures

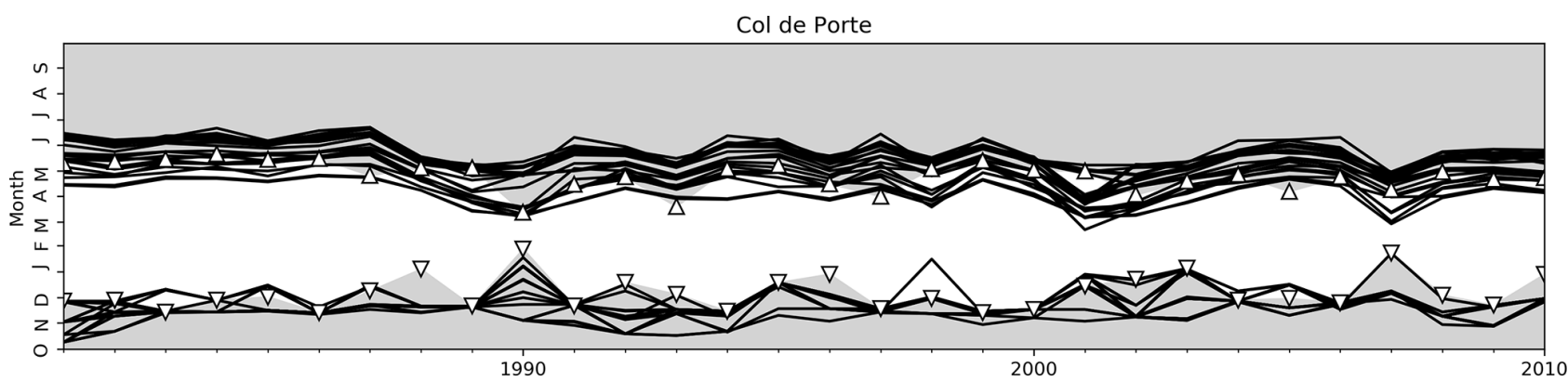

Reynolds Mountain East
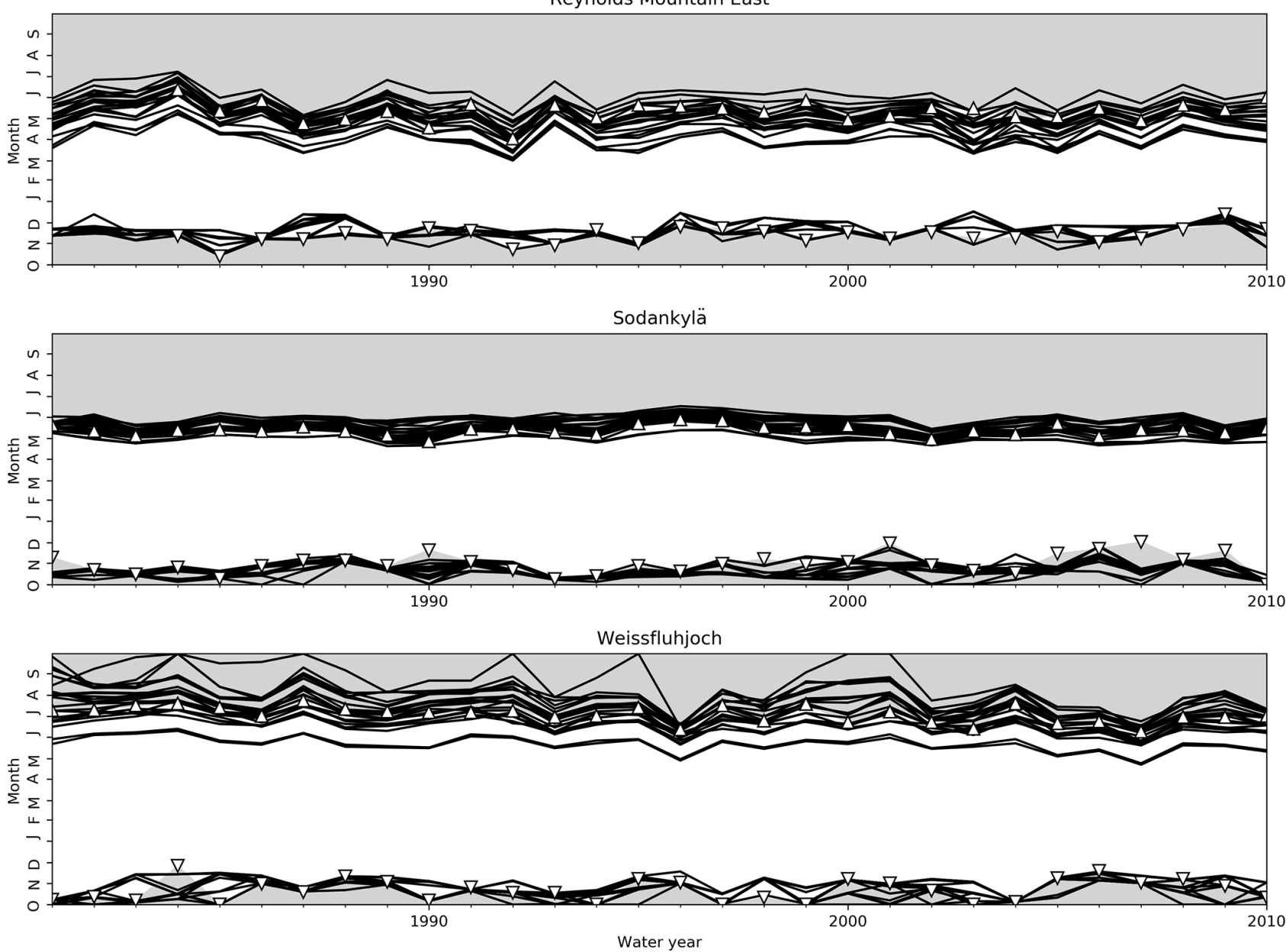

Figure A1. ESM-SnowMIP model predictions (lines) compared with observed start $(\nabla)$ and end $(\triangle)$ dates of continuous seasonal snow cover at the sites. Snow-free periods are shaded (ephemeral summer snow cover is not shown). 

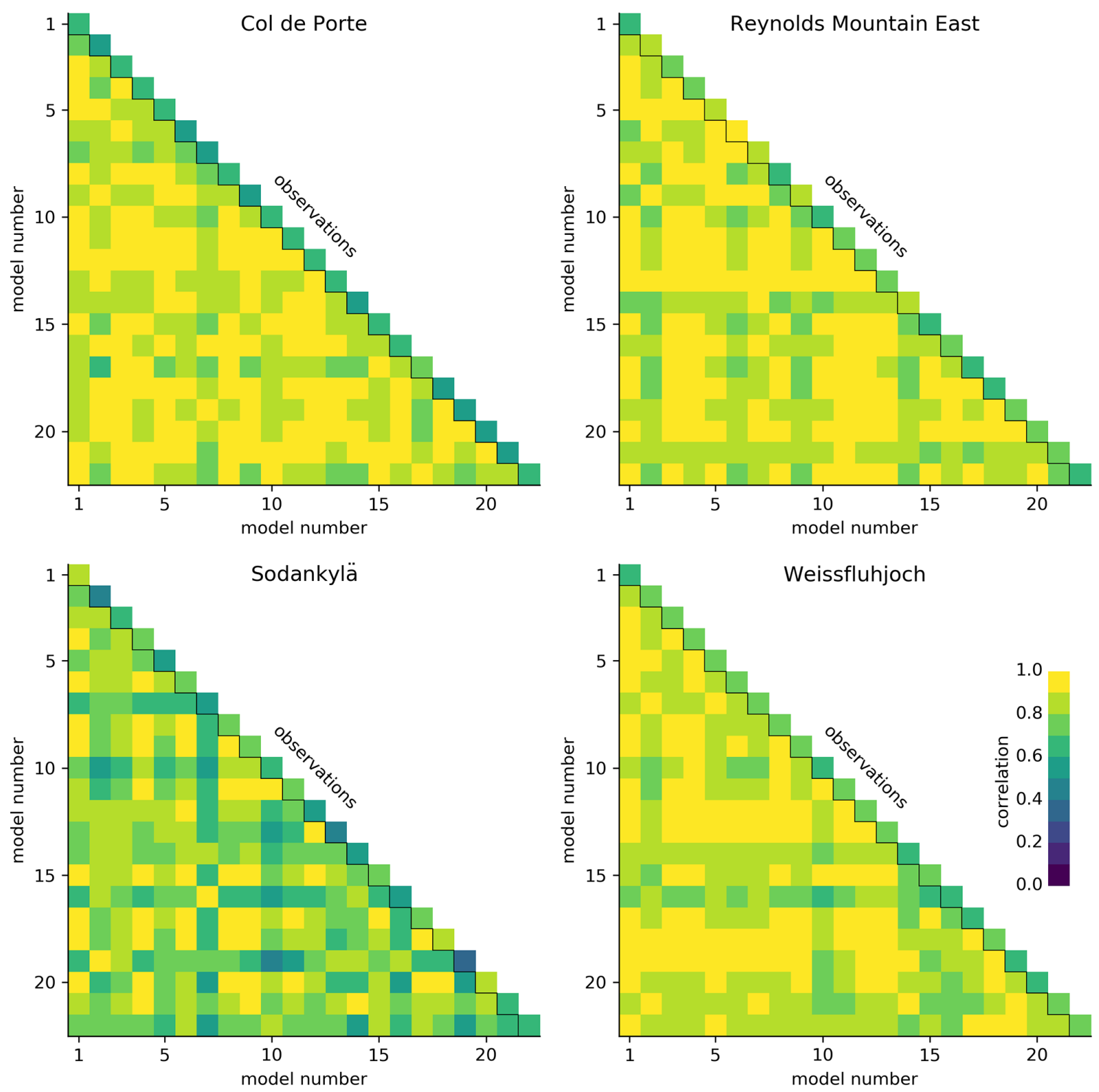

Figure A2. Correlations in interannual variations in snow cover duration between pairs of ESM-SnowMIP models. The upper diagonal in each figure shows correlations between individual models and observations at the sites. 
Data availability. The ESM-SnowMIP driving and evaluation data are available from https://doi.org/10.1594/PANGAEA.897575 (Menard and Essery, 2019).

Author contributions. RE prepared the manuscript with substantial contributions from all co-authors. HK provided the global reanalysis data, which LW extracted and interpolated for the study sites. All other co-authors either performed model simulations or provided field data.

Competing interests. The authors declare that they have no conflict of interest.

Acknowledgements. Analysis of the ESM-SnowMIP results was supported by NERC grant NE/P011926/1. Simulations were supported by the Russian Academy of Sciences Institute of Geography basic research programme for SPONSOR (project no. 0148-20190009) and by the Russian Science Foundation for SWAP (grant 1617-10039). Hyungjun Kim was supported by the Japan Society for the Promotion of Science KAKENHI (16H06291 and 18KK0117). We thank the two anonymous reviewers for their comments on this paper.

Financial support. This research has been supported by the Natural Environment Research Council (grant no. NE/P011926/1).

Review statement. This paper was edited by Ludovic Brucker and reviewed by two anonymous referees.

\section{References}

Brutel-Vuilmet, C., Ménégoz, M., and Krinner, G.: An analysis of present and future seasonal Northern Hemisphere land snow cover simulated by CMIP5 coupled climate models, The Cryosphere, 7, 67-80, https://doi.org/10.5194/tc-7-67-2013, 2013.

Dirmeyer, P. A., Gao, X., Zhao, M., Guo, Z., Oki, T., and Hanasaki, N.: GSWP-2: Multimodel Aaalysis and implications for our perception of the land surface, B. Am. Meteorol. Soc., 87, 13811398, 2006.

Essery, R., Rutter, N., Pomeroy, J., Baxter, R., Stähli, M., Gustafsson, D., Barr, A., Bartlett, P., and Elder, K.: SNOWMIP2: An evaluation of forest snow process simulations, B. Am. Meteorol. Soc., 90, 1120-1136, 2009.

Etchevers, P., Martin, E., Brown, R., Fierz, C., Lejeune, Y., Bazile, E., Boone, A., Dai, Y.-J., Essery, R., Fernandez, A., Gusev, Y., Jordan, R., Koren, V., Kowalczyk, E., Nasonova, O., Pyles, R. D., Schlosser, A., Shmakin, A. B., Smirnova, T. G., Strasser, U., Verseghy, D., Yamazaki, T., and Yang, Z. L.: Validation of the energy budget of an alpine snowpack simulated by several snow models (Snow MIP project), Ann. Glaciol., 38, 150-158, 2004.
Irannezhad, M., Ronkanen, A.-K., and Kløve, B.: Wintertime climate factors controlling snow resource decline in Finland, Int. J. Climatol., 36, 110-131, 2016.

Kim, H.: Global Soil Wetness Project Phase 3 atmospheric boundary conditions (Experiment 1), Data set, Data Integration and Analysis System (DIAS), https://doi.org/10.20783/DIAS.501, 2017.

Klein, G., Vitasse, Y., Rixen, C., Marty, C., and Rebetez, M.: Shorter snow cover duration since 1970 in the Swiss Alps due to earlier snowmelt more than to later snow onset, Clim. Change, 139, 637-649, 2016.

Krinner, G., Derksen, C., Essery, R., Flanner, M., Hagemann, S., Clark, M., Hall, A., Rott, H., Brutel-Vuilmet, C., Kim, H., Ménard, C. B., Mudryk, L., Thackeray, C., Wang, L., Arduini, G., Balsamo, G., Bartlett, P., Boike, J., Boone, A., Chéruy, F., Colin, J., Cuntz, M., Dai, Y., Decharme, B., Derry, J., Ducharne, A., Dutra, E., Fang, X., Fierz, C., Ghattas, J., Gusev, Y., Haverd, V., Kontu, A., Lafaysse, M., Law, R., Lawrence, D., Li, W., Marke, T., Marks, D., Ménégoz, M., Nasonova, O., Nitta, T., Niwano, M., Pomeroy, J., Raleigh, M. S., Schaedler, G., Semenov, V., Smirnova, T. G., Stacke, T., Strasser, U., Svenson, S., Turkov, D., Wang, T., Wever, N., Yuan, H., Zhou, W., and Zhu, D.: ESM-SnowMIP: assessing snow models and quantifying snowrelated climate feedbacks, Geosci. Model Dev., 11, 5027-5049, https://doi.org/10.5194/gmd-11-5027-2018, 2018.

Lejeune, Y., Dumont, M., Panel, J.-M., Lafaysse, M., Lapalus, P., Le Gac, E., Lesaffre, B., and Morin, S.: 57 years (1960-2017) of snow and meteorological observations from a mid-altitude mountain site (Col de Porte, France, 1325 of altitude), Earth Syst. Sci. Data, 11, 71-88, https://doi.org/10.5194/essd-11-712019, 2019.

López-Moreno, J. I., Pomeroy, J. W., Revuelto, J., and VicenteSerrano, S. M.: Response of snow processes to climate change: spatial variability in a small basin in the Spanish Pyrenees, Hydrol. Process., 27, 2637-2650, 2013.

Marty, C. and Meister, R.: Long-term snow and weather observations at Weissfluhjoch and its relation to other high-altitude observatories in the Alps, Theor. Appl. Climatol., 110, 573-583, 2012.

Menard, C. and Essery, R.: ESM-SnowMIP meteorological and evaluation datasets at ten reference sites (in situ and bias corrected reanalysis data), PANGAEA, https://doi.org/10.1594/PANGAEA.897575, 2019.

Ménard, C. B., Essery, R., Barr, A., Bartlett, P., Derry, J., Dumont, M., Fierz, C., Kim, H., Kontu, A., Lejeune, Y., Marks, D., Niwano, M., Raleigh, M., Wang, L., and Wever, N.: Meteorological and evaluation datasets for snow modelling at 10 reference sites: description of in situ and bias-corrected reanalysis data, Earth Syst. Sci. Data, 11, 865-880, https://doi.org/10.5194/essd11-865-2019, 2019.

Menard, C. B., Essery, R., Krinner, G., Arduini, G., Bartlett, P., Boone, A., Brutel-Vuilmet, C., Burke, E., Cuntz, M., Dai, Y., Decharme, B., Dutra, E., Fang, X., Fierz, C., Gusev, Y., Hagemann, S., Haverd, V., Kim, H., Lafaysse, M., Marke, T., Nasonova, O., Nitta, T., Niwano, M., Pomeroy, J., Schädler, G., Semenov, V., Smirnova, T., Strasser, U., Swenson, S., Turkov, D., Wever, N., and Yuan, H.: Scientific and human errors in a snow model intercomparison, B. Am. Meteorol. Soc., https://doi.org/10.1175/BAMS-D-19-0329.1, in press, 2020. 
Mudryk, L., Santolaria-Otín, M., Krinner, G., Ménégoz, M., Derksen, C., Brutel-Vuilmet, C., Brady, M., and Essery, R.: Historical Northern Hemisphere snow cover trends and projected changes in the CMIP6 multi-model ensemble, The Cryosphere, 14, 24952514, https://doi.org/10.5194/tc-14-2495-2020, 2020.

Mudryk, L. R., Kushner, P. J., Derksen, C., and Thackeray, C.: Snow cover response to temperature in observational and climate model ensembles, Geophys. Res. Lett., 44, 919-926, 2017.

Musselman, K. N., Clark, M. P., Liu, C., Ikeda, K., and Rasmussen, R.: Slower snowmelt in a warmer world, Nat. Clim. Change, 7, 214-219, 2017.

Nayak, A., Marks, D., Chandler, D. G., and Seyfried, M.: Long-term snow, climate, and streamflow trends at the Reynolds Creek Experimental Watershed, Owyhee Mountains, Idaho, United States, Water Resour. Res., 46, W06519, https://doi.org/10.1029/2008WR007525, 2010.

Pepin, N., Bradley, R. S., Diaz, H. F., Baraer, M., Caceres, E. B., Forsythe, N., Fowler, H., Greenwood, G., Hashmi, M. Z., Liu, X. D., Miller, J. R., Ning, L., Ohmura, A., Palazzi, E., Rangwala, I., Schöner, W., Severskiy, I., Shahgedanova, M., Wang, M. B., Williamson, S. N., and Yang, D. Q.: Elevation-dependent warming in mountain regions of the world, Nat. Climate Change, 5, 424-430, 2015.

$\mathrm{Qu}, \mathrm{X}$. and Hall, A.: On the persistent spread in snow-albedo feedback, Clim. Dynam., 42, 69-81, 2014.

Randall, D. A., Bitz, C. M., Danabasoglu, G., Denning, A. S., Gent, P. R., Gettelman, A., Griffies, S. M., Lynch, P., Morrison, H., Pincus, R., and Thuburn, J.: 100 Years of Earth System Model Development, Meteorol. Monogr., 59, 12.1-12.66, 2019.

Sen, P. B.: Estimates of the regression coefficient based on Kendall's tau, J. Am. Stat. Assoc., 63, 1379-1389, 1968.
Slater, A. G., Schlosser, C. A., Desborough, C. E., Pitman, A. J., Henderson-Sellers, A., Robock, A., Vinnikov, K. Y., Entin, J., Mitchell, K., Chen, F., Boone, A., Etchevers, P., Habets, F., Noilhan, J., Braden, H., Cox, P. M., de Rosnay, P., Dickinson, R. E., Yang, Z.-L., Dai, Y.-J., Zeng, Q., Duan, Q., Koren, V., Schaake, S., Gedney, N., Gusev, Y. M., Nasonova, O. N., Kim, J., Kowalczyk, E. A., Shmakin, A. B., Smirnova, T. G., Verseghy, D., Wetzel, P., and Xue, Y.: The representation of snow in land surface schemes: Results from PILPS 2(d), J. Hydrometeorol., 2, 7-25, 2001.

van den Hurk, B., Kim, H., Krinner, G., Seneviratne, S. I., Derksen, C., Oki, T., Douville, H., Colin, J., Ducharne, A., Cheruy, F., Viovy, N., Puma, M. J., Wada, Y., Li, W., Jia, B., Alessandri, A., Lawrence, D. M., Weedon, G. P., Ellis, R., Hagemann, S., Mao, J., Flanner, M. G., Zampieri, M., Materia, S., Law, R. M., and Sheffield, J.: LS3MIP (v1.0) contribution to CMIP6: the Land Surface, Snow and Soil moisture Model Intercomparison Project - aims, setup and expected outcome, Geosci. Model Dev., 9, 2809-2832, https://doi.org/10.5194/gmd-9-2809-2016, 2016.

Wu, X., Che, T., Li, X., Wang, N., and Yang, X.: Slower snowmelt in spring along with climate warming across the Northern Hemisphere, Geophys. Res. Lett., 45, 12,331-12,339, 2018.

Yoshimura, K. and Kanamitsu, M.: Dynamical global downscaling of global reanalysis, Mon. Weather Rev., 136, 2983-2998, 2008.

Zhang, T., Stackhouse, P. W., Gupta, S. K., Cox, S. J., Mikovitz, J. C., and Hinkelman, L. M.: The validation of the GEWEX SRB surface shortwave flux data products using BSRN measurements: A systematic quality control, production and application approach, J. Quan. Spectrosc. Ra., 122, 127-140, 2013.

Zhang, T., Stackhouse, P. W., Gupta, S. K., Cox, S. J., and Mikovitz, J. C.: The validation of the GEWEX SRB surface longwave flux data products using BSRN measurements, J. Quan. Spectrosc. Ra., 150, 134-147, 2015. 